\title{
Subchronic Toxicity of Fish Oil Concentrates in Male and Female Rats
}

\author{
P. Isaac Rabbani, Hamida Z. Alam, Stuart J. ChirTel, Robert E. Duvall, \\ Randolph C. JACKSON and George RuFFIN \\ Risk Assessment, HFS-308, Center for Food Safety and Applied Nutrition, Food and Drug Administration, \\ 200 C Street, S.W., Washington, D.C. 20204, USA \\ (Received September 11, 2000)
}

\begin{abstract}
Summary There are an overwhelming number of reports indicating the beneficial effects of fish oil supplements in human and animal nutrition. The purpose of this study, second in a series, was to evaluate the effects, particularly those that may be harmful, of high-dose, long-term consumption of fish oil concentrates (FOC) using male and female rats. One hundred and twenty male and 120 female rats were gavaged daily with oils and oil mixtures in a volume equal to $0.5 \%$ body weight $(5 \mathrm{~mL} / \mathrm{kg} / \mathrm{d})$ for 13 weeks. The administered oils were corn oil, pure menhaden oil (MO), pure MaxEPA ${ }^{\circledR}$ fish oil or different mixtures of corn oil with MO. The stability and the homogeneity of the dosing solutions were tested under study conditions. The animals received isocaloric and isonitrogenous diets throughout. Food and pure water were supplied ad libitum. At the end of the in-life phase of the study, the animals were anaesthetized with $\mathrm{CO}_{2}$ and humanely killed by exsanguination. Blood and other tissues were prepared for various clinical, histopathological and laboratory tests. Some beneficial effects of FOC, such as reduction in total serum cholesterol, in rats were confirmed. However, we also observed a significant reduction in absolute amount of serum HDL and a significant increase in relative liver and spleen weights in both sexes with the high dose of FOC. High doses of FOC $(5 \mathrm{~mL} / \mathrm{kg} / \mathrm{d})$ reduced serum iron and vitamin E concentrations. A reduction in osmotic fragility of $\mathrm{RBC}$ as well as an increase in RBC deformity were also observed in rats treated with high doses of FOC. These rats showed a significant overall increase in WBC count. We conclude that in rats, subchronic consumption of high levels of FOC can be beneficial but may also be harmful because of induction of clinical abnormalities including increased red cell deformity, increased relative liver and spleen weights, and reduced serum HDL, iron and vitamin E concentrations.
\end{abstract}

Key Words subchronic toxicity, fish oil concentrates, $n-3$ fatty acids

Fish oil concentrates (FOC) which contain omega-3 fatty acids are becoming increasingly popular due to their purported beneficial effects in prevention and/or treatment of many diseases including cardiovascular disease and cancer (1-5). Some scientists suggest prophylactic use of $n-3$ fatty acids through a broad food enrichment (6). Reports concerning the beneficial effects of FOC supplements in health and diseases are conflicting $(7-10)$. Some reports indicate that there may be harmful effects associated with either prolonged ingestion or acute ingestion of large quantities of the omega3 fatty acids (11). These include development of aneurisms and increased risk of stroke (12) and infections (13), modulation of the immune system (14), enhancement of ethanol- (15) or acetaminophen-induced hepatotoxicity (16), lipidosis (17), enhancement of fatty streak (18) and plaque formation (19) in the aorta, and detrimental effects on glucose tolerance in type II diabetics $(20)$. Other harmful effects related to the consumption of FOC were reported in both animals (21) and humans (22). A study was conducted with MaxEPA $^{\circledR}$, a commercially available FOC, to obtain an indication of any clinical, biochemical, or pathological problems that might result from a 65 -day $(5 \mathrm{~d} /$ wk for
13 weeks) high-level administration of this FOC (23). This follow-up 90-day study ( $7 \mathrm{~d} /$ wk for 13 weeks) presented herein was performed using MO, a relatively crude fish oil that was well characterized and provided by the National Marine Fisheries Service (NMFS) for use in clinical or non-clinical studies. To facilitate comparisons with our previous study, twenty male and twenty female rats were also treated with MaxEPA ${ }^{\circledR}$ at the high dose level of $5 \mathrm{~mL} / \mathrm{kg} / \mathrm{d}$ for 13 weeks.

\section{MATERIALS AND METHODS}

The oils, animal care and treatments. The National Marine Fisheries Service (NMFS), Southeast Fisheries Center, Charleston Laboratory, Charleston, SC, USA, provided MO in polyethylene plastic containers. This crude fish oil contained a total of $29.9 \% n-3$ fatty acids (FA) including 9.2\% docosahexaenoic acid (DHA) and $12.9 \%$ eicosapentaenoic acid (EPA). Contaminants in the oil, determined by the NMFS, were polychlorinated biphenyl (PCB) $<0.05$ ppm and dichlorodiphenyltrichloroethane (DDT) $<0.004 \mathrm{ppm}$. The oil also contained $0.02 \%$ TBHQ, an antioxidant, and $2.2 \mathrm{mg} / \mathrm{mL}$ of vitamin E. MaxEPA ${ }^{\circledR}$ was provided by R.P. Scherer Company, Clearwater, FL, USA. This FOC provided a 
total of $35 \%$ omega-3 FA, including $12 \%$ DHA and $17.8 \% \mathrm{EPA}$, and $2 \mathrm{mg}$ vitamin $\mathrm{E} / \mathrm{g}$ oil. Contaminants in the oil were determined by the manufacturer, and the values for $\mathrm{PCB}, \mathrm{Hg}, \mathrm{Pb}$, As, and $\mathrm{Cd}$ were $<1 \mathrm{ppm}$, and for pesticides, $<0.1 \mathrm{ppm}$. Mazzola ${ }^{\circledR}$ Corn Oil (CO), the control article, was a gift from Dr. Mark Bieber (Best Foods, Union, NJ, USA). Samples of the CO were shipped to NMFS for the analysis of TBHQ and vitamin $\mathrm{E}$. The oil was then fortified with vitamin $\mathrm{E}$ and TBHQ (Tenox $20 \mathrm{~A}$ ) to contain $0.02 \% \mathrm{TBHQ}$ and $2.2 \mathrm{mg}$ vitamin $\mathrm{E}$ per $\mathrm{g}$ of oil, an amount of these chemicals equal to that found in MO. The oils had a specific gravity. of $0.93 \mathrm{~g} / \mathrm{mL}$. All the oils were diffused and blanketed with $\mathrm{N}_{2}$ in the original plastic containers, protected against light and stored under similar conditions $\left(-20^{\circ} \mathrm{C}\right)$ until used.

Four week-old male and female Sprague Dawley rats, 120 of each sex, were purchased from Charles River Breeding Lab. Inc., Wilmington, MA, USA (Raleigh, N.C. colony). The animals were quarantined and acclimated in the same room for 13 days. They were then weighed and grouped in $5 \mathrm{~g}$ intervals, randomized and assigned to six treatment groups of 20 rats per treatment per sex. The animals were eartagged for identification. The rats were housed, individually, in suspended stainless steel cages with screen bottoms. The animal room had a $12 \mathrm{~h}$ light-dark cycle, temperature of $18-24^{\circ} \mathrm{C}$ and a relative humidity of $40-70 \%$. There was a morning and an afternoon check for sick or dead animals. Food and water were checked daily. During the weekly weighing and daily gavaging, the animals were thoroughly examined, and any signs of toxicity were recorded. Purina ${ }^{\mathrm{TM}}$ Ground Chow was supplied by Purina $^{\text {TM }}$ Mills Co., St. Louis, MO, USA, and stored at $4^{\circ} \mathrm{C}$. Food and water (AQUA COOL ${ }^{\circledR}$ Ultrapure Water, Watertown, MA, USA) were supplied ad libitum during the quarantine and during the live-phase of the study. The feeding cups were filled with fresh food once a week, using a 1741 Dry Weight Dispenser (Voland Corp., White Plains, NY, USA), and weekly food con- sumption was calculated. The diets were isocaloric and isonitrogenous throughout. The animal care was monitored by the FDA's Institutional Animal Care and Use Committee (IACUC). The Guide for the Care and Use of Laboratory Animals (Institute of Laboratory Animal Resources Council, National Academy of Sciences, 1986) was followed throughout. All clinical and laboratory tests adhered to the Good Laboratory Practice Guidelines.

The dosing solutions were administered daily for 13 weeks by gavage of oils in a volume equal to $0.5 \%$ of an animal's body weight. This procedure was previously described $(23,24)$. This amount of administered oil was high but did not cause diarrhea in the animals. The calculated human equivalent of the highest dose is about $19 \mathrm{~g}$ of $n-3 \mathrm{FA} / \mathrm{d}$ for $\mathrm{MO}$ and $23 \mathrm{~g}$ of $n-3 \mathrm{FA} / \mathrm{d}$ for MaxEPA ${ }^{\circledR}$ for a $65 \mathrm{~kg}$ human. Five $\mathrm{mL}$ of dosing solutions contained the following $\mathrm{mL}$ of $\mathrm{MO}$ diluted with corn oil: 0.0 (Control, pure corn oil); 0.1, 0.5, 2.5 and 5 (the highest dose, pure MO), representing treatment numbers I, II, III, IV and V, respectively (Table 1). Treatment number VI was pure MaxEPA ${ }^{\circledR}$. Light-initiated autoxidation (25), was avoided by preparing the dosing solutions, $4 \mathrm{~L}$ at a time, under yellow light. The oils were then sampled from top, middle and bottom and tested for FA profile (26) to ensure homogeneity of the dosing solutions. A gas-liquid chromatograph (HP 5880A, Rockville, MD, USA) equipped with a wall coated open tubular capilary column (Supelco-10, $30 \mathrm{~m}, 0.32 \mathrm{~mm}$ id, and $0.25 \mu \mathrm{df}$, Supelco, Supelco Park, Bellafonte, PA 16823) was used. The oils were then dispensed into $150 \mathrm{~mL}$ prescription bottles covered with aluminum foil, diffused and blanketed with $\mathrm{N}_{2}$, capped, labeled and stored at $-20^{\circ} \mathrm{C}$ until used. Each bottle was used for only one day of dosing. The stability data of all the oils, CO, MO, MaxEPA ${ }^{(\mathbb{R})}$ and the oil content of the diet were provided by the suppliers. However, we also confirmed the data by measuring the FA profile of the oils and of the dosing solutions as well as their peroxide values (27). FA profile of the diet was also de-

Table 1. Description of the treatments and characteristics of the oils.

\begin{tabular}{|c|c|c|c|c|c|c|}
\hline \multirow{2}{*}{ Treatment number ${ }^{2}$} & \multicolumn{2}{|c|}{$\mathrm{mL}$ of } & \multirow{2}{*}{$n-3 / n-6$ Ratio } & \multicolumn{2}{|c|}{$\begin{array}{l}\text { Concentrations of } n-3 \text { FAs } \\
(\mathrm{mg} / \mathrm{g} \text { of oil })^{1}\end{array}$} & \multirow{2}{*}{$\mathrm{PV}(\mathrm{meq} / \mathrm{kg})$} \\
\hline & Corn oil & Menhaden oil & & $\mathrm{EPA}$ & DHA & \\
\hline I & 5.00 & 0.00 & 0.02 & ND & ND & $1.0 \pm 0.1$ \\
\hline II & 4.90 & 0.10 & 0.17 & $2.6 \pm 0.5$ & $1.8 \pm 0.2$ & $1.1 \pm 0.2$ \\
\hline III & 4.50 & 0.50 & 0.77 & $11.8 \pm 0.7$ & $8.4 \pm 0.6$ & $1.3 \pm 0.1$ \\
\hline IV & 2.50 & 2.50 & 3.79 & $58.8 \pm 0.7$ & $42.7 \pm 0.6$ & $2.1 \pm 0.1$ \\
\hline $\mathrm{V}$ & 0.00 & $\begin{array}{c}5.00 \\
\text { MaxEPA }^{(8)}\end{array}$ & 7.55 & $116.9 \pm 2.3$ & $85.6 \pm 1.6$ & $2.8 \pm 0.2$ \\
\hline VI & 0.00 & 5.00 & 8.30 & $135.9 \pm 5.7$ & $99.9 \pm 5.4$ & $1.2 \pm 0.3$ \\
\hline
\end{tabular}

\footnotetext{
${ }^{1}$ The values are $\mathrm{M} \pm \mathrm{SE}$ of seven duplicate determinations over 3 mo.

${ }^{2}$ Each oil treatment was administered daily in a volume equal to $0.5 \%$ body weight for 13 weeks.

Concentration of vitamin $\mathrm{E}$ in the dosing solutions (mg/g oil): treatment I (corn oil control), 1.00; II, 1.02; III, 1.12; IV, 1.35; V (pure Menhaden oil), 2.20; and VI (pure MaxEPA ${ }^{\circledR}$ ), 2.00.

FA, fatty acids. EPA, eicosapentaenoic acids (20:5,n-3 FA). DHA, docosahexaenoic acid (22:6,n-3 FA). ND, not detected. $\mathrm{PV}$, peroxide value.
} 
Table 2. Stability tests: Fatty acid profiles of oils and extracted oil from food, and peroxide values at the beginning and at the end of the study. ${ }^{1}$

\begin{tabular}{|c|c|c|c|c|c|c|c|c|}
\hline \multirow{2}{*}{ Fatty acid } & \multicolumn{4}{|c|}{ Beginning of the study } & \multicolumn{4}{|c|}{ End of the study } \\
\hline & $\mathrm{CO}$ & MO & Max & Chow & $\mathrm{CO}$ & MO & $\operatorname{Max}$ & Chow \\
\hline C14:0 & 0.0 & 6.3 & 6.5 & 0.7 & 0.0 & 6.4 & 6.4 & 0.7 \\
\hline C14: 1 & 0.0 & 0.1 & 0.0 & 0.1 & 0.0 & 0.1 & 0.0 & 0.1 \\
\hline $\mathrm{C} 16: 0$ & 9.5 & 15.8 & 15.8 & 13.7 & 9.1 & 15.7 & 16.0 & 14.9 \\
\hline $\mathrm{C} 16: 1$ & 0.1 & 8.4 & 7.9 & 0.9 & 0.1 & 8.4 & 7.7 & 1.0 \\
\hline $\mathrm{C} 18: \mathrm{O}$ & 1.8 & 2.4 & 3.0 & 3.5 & 1.8 & 2.4 & 2.9 & 3.5 \\
\hline C18: 1 & 29.3 & 10.8 & 8.0 & 19.8 & 29.3 & 10.4 & 7.4 & 21.1 \\
\hline $\mathrm{C} 18: 2$ & 56.9 & 1.2 & 1.3 & 45.8 & 57.1 & 1.2 & 1.0 & 47.7 \\
\hline $\mathrm{C} 18: 3$ & 0.9 & 1.0 & 0.8 & 4.2 & 0.9 & 0.9 & 0.7 & 4.7 \\
\hline $\mathrm{C} 20: 0$ & 0.5 & 0.0 & 0.2 & 0.4 & 0.5 & 0.1 & 0.3 & 0.4 \\
\hline $\mathrm{C} 20: 1$ & 0.2 & 2.9 & 1.5 & 0.5 & 0.3 & 2.9 & 1.7 & 0.5 \\
\hline $\mathrm{C} 20: 2$ & 0.0 & 0.2 & 0.2 & $<0.1$ & 0.0 & 0.2 & 0.1 & $<0.1$ \\
\hline $\mathrm{C} 20: 3$ & 0.0 & 0.2 & 0.1 & $<0.1$ & 0.0 & 0.1 & 0.1 & $<0.1$ \\
\hline $\mathrm{C} 20: 4$ & 0.0 & 0.4 & 0.9 & 0.1 & 0.0 & 0.4 & 0.9 & 0.1 \\
\hline $\mathrm{C} 20: 5$ & 0.0 & 15.0 & 17.1 & 1.2 & 0.0 & 15.1 & 17.9 & 1.3 \\
\hline $\mathrm{C} 22: 0$ & 0.1 & 0.1 & 0.1 & 0.4 & 0.1 & 0.1 & 0.1 & 0.4 \\
\hline $\mathrm{C} 22: 1$ & 0.0 & 0.3 & 0.2 & 0.2 & 0.0 & 0.3 & 0.1 & $<0.1$ \\
\hline $\mathrm{C} 22: 6$ & 0.0 & 11.2 & 12.8 & $<0.1$ & 0.0 & 11.2 & 13.6 & $<0.1$ \\
\hline $\mathrm{C} 24: 0$ & 0.1 & 0.0 & 0.0 & 1.4 & 0.2 & 0.0 & 0.0 & 1.5 \\
\hline $\mathrm{C} 24: 1$ & 0.0 & 0.5 & 0.7 & $<0.1$ & 0.0 & 0.5 & 0.6 & $<0.1$ \\
\hline Others & 0.6 & 23.2 & 22.9 & 7.0 & 0.6 & 23.6 & 22.5 & 2.0 \\
\hline PV (meq/kg) & 0.8 & 2.7 & 0.8 & ND & 1.0 & 2.8 & 1.4 & ND \\
\hline
\end{tabular}

${ }^{1}$ The values for fatty acid profiles are the average of three determinations and are expressed as $\%$ of total oil. CO, corn oil control. MO, menhaden oil. Max, MaxEPA ${ }^{\circledR}$ oil. Chow, Ralston Purina ${ }^{\mathrm{TM}}$ Ground Chow (No. 5002). PV, peroxide value. ND, not determined.

termined at the beginning and at the end of feeding period (Centech Laboratories St. Louis, MO, USA) to provide stability data for the test and control articles and the data are summarized in Table 2.

Euthanasia, necropsy and clinical tests. At the conclusion of the in-life phase of the study, animals were anaesthetized with excess $\mathrm{CO}_{2}$, weighed, humanely killed by exsanguination via the posterior vena cava, and necropsied. During each day of necropsy, four rats from each treatment group (total of 24 rats from each sex) were randomly selected for euthanasia. Blood was drawn using a $20 \mathrm{~mL}$ plastic syringe and a stainless steel needle, $21 \mathrm{~g}$ and 1.5 inch long. Osmotic fragility of the red blood cells (OFRBC) was determined immediately according to the method of Dacie and Lewis (28). Prothrombin time (PT) and activated partial thromboplastin time (aPTT), two of the many coagulation indices, were determined by using Coag-A-Mate Model X2 (Organon Teknika, Oklahoma City, OK, USA), immediately after necropsy. Whole blood, serum and plasma specimens were also prepared for hematological and clinical chemistry tests by MetPath company (MetPath Inc., Rockville, MD, USA). These included complete blood count (CBC) with differentials, platelet counts, hemoglobin and hematocrit, mean corpuscular volume (MCV), mean corpuscular hemoglobin (MCH), $\mathrm{MCH}$ concentration (MCHC), red blood cell distribution width (RDW), mean platelet volume (MPV), \% neutrophils, lymphocytes, monocytes, eosinophil and platelets, glu- cose, blood urea nitrogen (BUN), creatinine, BUN/creatinine ratio, $\mathrm{Na}, \mathrm{K}, \mathrm{Cl}, \mathrm{Ca}, \mathrm{P}, \mathrm{Fe}$, uric acid, total serum protein, albumin (A), globulin (G), A/G ratio, serum glutamate oxaloacetate transaminase (SGOT), serum glutamic pyruvic transaminase (SGPT), SGOT/SGPT ratio, $\gamma$-glutamyl-transpeptidase (GGTP), alkaline phosphatase, lactic dehydrogenase (LDH), total and direct bilirubin, triglycerides, cholesterol, high density lipoprotein (HDL) and serum vitamin $\mathrm{E}$.

A thorough post-mortem gross examination was performed, and it included all external orifices, the pelvic, abdominal, thoracic and cranial cavities with their viscera and the carcass. Special attention was given to the aorta and distal portion of the colon for possible gross lesions. The following organs were removed, cleaned and weighed: adrenal glands, brain, heart, kidneys, liver, spleen, testes, ovaries and thymus. A full screen histopathology evaluation was performed on the following tissues/organs: adrenal glands, aorta, brain, sternum, esophagus, epididymis, one eye, heart, kidneys, lung, liver, pituitary gland, mammary glands, ovary, pancreas, prostate, submaxillary salivary glands, seminal vesicles, skeletal muscle (psoas), skin (right thoracic), stomach (glandular and non-glandular), spleen, testes, thymus, thyroid, parathyroid, trachea, urinary bladder and uterus. All trimmed tissues were processed, embedded in paraffin, sectioned at 5 microns, stained with hematoxylin and eosin and examined by light microscopy. Special stains, oil-red-o and osmium tetroxide 
for fat, periodic acid schiff (PAS) reaction with and without diastase for glycogen, Gomori for iron and alizarin for calcium were used on selected sections of lung, liver, kidneys and spleen. Bone specimens (sternum) were removed, cleaned and decalcified in a solution composed of equal volume of $45 \%$ formic acid and $25 \%$ of sodium citrate before being processed as for other tissues. Likewise, duodenum, cecum, colon, and rectum were prepared and processed as described.

Liver specimens were collected for a qualitative histochemical test for peroxisomes (29). This test was performed on liver specimens, 3 rats for each of the six treatment groups per sex. The liver specimens were coated with starch powder, frozen in liquid nitrogen, placed into precooled vials and stored at $-30^{\circ} \mathrm{C}$ until further processing. Ten micron sections of the tissues were obtained using a cryostat $\left(-15^{\circ} \mathrm{C}\right)$ and were then prefixed with a $10 \%$ cold formalin $(\mathrm{pH}=7)$ for 15 minutes and incubated in filtered diaminobenzidine solution (DAB) for $1 \mathrm{~h}$. The medium consisted of $10 \mathrm{~mL}$ of $1 \% \mathrm{H}_{2} \mathrm{O}_{2}, 49 \mathrm{~mL}$ of $50 \mathrm{~mm}$ 2-amino-2-methyl-1,3propanediol buffer ( $\mathrm{pH}=8.8$ ), $100 \mathrm{mg}$ of DAB and $5 \mathrm{~mL}$ of $1 \mathrm{mM} \mathrm{MnCl}_{2}$. The sections were then counter stained with Mayer's hematoxylin, washed with tap water, dehydrated with alcohol and xylene and mounted. The peroxisomes were identified as brownish black areas under a microscope.

Statistical Methods. Mean separation using one and two-way analysis of variance (ANOVA) or covariance with appropriate comparisons in the presence of significant ANOVA was used to determine dose, sex and dose $\times$ sex interactions $(30)$. Sex effects were determined by simple $t$-test. Dose effects were determined by mean comparisons using a two-sided LSD test. In the absence of significant dose and sex interactions, the overall effects were tested by two-way ANOVA. The Shapiro-Wilk test for normality of values for all the variables was used. When the test indicated that the values were not "normal", nonparametric procedures were used for statistical analysis of that variable. All differences with $p \leq 0.05$ were deemed statistically significant.

\section{RESULTS}

Average weekly food consumption and weekly weight gain are summarized in Table 3 . Fish oil consumption showed little or no effect on these parameters except at the highest dose level where food consumption increased significantly. In general, the average weekly weight gain was not affected by treatment. High doses of fish oils caused a significant increase in relative liver and spleen weights (Table 4), but did not affect the relative weights of other tissues.

Serum triglyceride (TG) level was not affected by fish oil, while the total serum cholesterol (TCh) and absolute amount of serum HDL were reduced significantly. These effects were more pronounced in female than in male rats (Table 5). However, both total cholesterol and the HDL data in the three female groups (control, treatments I \& II) had very high standard deviations. Nevertheless, the dose effect toward lower serum TCh and HDL determined by a two-way ANOVA, was highly significant $(p<0.0002)$.

Two of the factors involved in the coagulation process, plasma PT and aPPT, were not affected by fish oil treatments (Table 6). A 10\% increase in the white blood cell count was observed in both sexes. This increase in leukocyte count was statistically significant when the male and female data were pooled and a twoway ANOVA was applied $(p<0.0056)$. The mean platelet volume in the two highest dose groups was significantly reduced while the RDW was significantly elevated in both sexes in the highest dose levels. There was also a trend in lessening of OFRBC, but this was statistically significant only when two-way ANOVA was applied (Table 6). Clinical chemistry data are presented in Table 7. Serum concentration of BUN increased in female rats receiving the highest dose of MO, while the concentration of serum creatinine significantly declined in the female rats. In male rats, some serum enzyme activities (SGOT and LDH) were affected by the high doses

Table 3. Average weekly food consumption and weight gain.

\begin{tabular}{|c|c|c|c|c|}
\hline \multirow{3}{*}{$\begin{array}{c}\text { Treatment }^{1} \\
(\mathrm{~mL} \text { of } \mathrm{FO} / \mathrm{kg} / \mathrm{d})\end{array}$} & \multicolumn{4}{|c|}{$\mathrm{g} / \mathrm{wk} / \mathrm{rat}$} \\
\hline & \multicolumn{2}{|c|}{ Food consumption } & \multicolumn{2}{|c|}{ Weight gain } \\
\hline & Male & Female & Male & Female \\
\hline 0.00 (corn oil control) & $138 \pm 14$ & $105 \pm 9$ & $26 \pm 4$ & $10 \pm 3$ \\
\hline 0.10 & $145 \pm 9$ & $106 \pm 11$ & $28 \pm 3$ & $10 \pm 2$ \\
\hline 0.50 & $140 \pm 16$ & $105 \pm 12$ & $25 \pm 5$ & $10 \pm 2$ \\
\hline 2.50 & $146 \pm 17$ & $109 \pm 12$ & $27 \pm 5$ & $11 \pm 2$ \\
\hline $5.00{\text { (menhaden oil })^{2}}^{2}$ & $147 \pm 11^{\mathrm{a}}$ & $112 \pm 9^{c}$ & $26 \pm 4$ & $12 \pm 2^{\mathrm{e}}$ \\
\hline $5.00\left(\text { MaxEPA }^{(R)} \text { oil }\right)^{2}$ & $151 \pm 16^{\mathrm{b}}$ & $114 \pm 7^{\mathrm{d}}$ & $27 \pm 4$ & $11 \pm 2$ \\
\hline Dose effect ${ }^{3}$ & \multicolumn{2}{|c|}{$p<0.0005$} & \multicolumn{2}{|c|}{ NS } \\
\hline
\end{tabular}

\footnotetext{
${ }^{1}$ The oils were administered daily in a volume equal to $0.5 \%$ body weight for 13 weeks.

${ }^{2}$ Frequent food spillage in high dose groups.

${ }^{3}$ By two-way ANOVA (no significant dose $\times$ sex interaction).

NS, statistically not significant; ${ }^{\mathrm{a}} p<0.0298,{ }^{\mathrm{b}} p<0.0034,{ }^{\mathrm{c}} p<0.0238,{ }^{\mathrm{d}} p<0.0069,{ }^{\mathrm{e}} p<0.0057$.

The values are $\mathrm{M} \pm \mathrm{SD}$ of $19-20$ rats. FO, fish oil.
} 
Table 4. Relative liver and spleen weights.

\begin{tabular}{|c|c|c|c|c|}
\hline \multirow{2}{*}{$\begin{array}{c}\text { Treatment }^{1} \\
(\mathrm{~mL} \text { of } \mathrm{FO} / \mathrm{kg} / \mathrm{d})\end{array}$} & \multicolumn{2}{|c|}{ Liver $(\mathrm{g} / 100 \mathrm{~g})$} & \multicolumn{2}{|c|}{ Spleen $(\mathrm{mg} / 100 \mathrm{~g})$} \\
\hline & Male & Female & Male & Female \\
\hline 0.00 (corn oil control) & $3.6 \pm 0.55$ & $3.7 \pm 0.39$ & $158 \pm 31$ & $189 \pm 23$ \\
\hline 0.10 & $3.5 \pm 0.25$ & $3.7 \pm 0.54$ & $151 \pm 28$ & $192 \pm 21$ \\
\hline 0.50 & $3.5 \pm 0.22$ & $3.8 \pm 0.52$ & $160 \pm 24$ & $185 \pm 39$ \\
\hline 2.50 & $3.6 \pm 0.24$ & $4.0 \pm 0.57$ & $154 \pm 26$ & $197 \pm 46$ \\
\hline 5.00 (menhaden oil) & $3.9 \pm 0.34^{\mathrm{a}}$ & $4.0 \pm 0.37^{\mathrm{c}}$ & $171 \pm 22$ & $205 \pm 33^{f}$ \\
\hline $5.00\left(\mathrm{MaxEPA}^{\circledR} \mathrm{oil}\right)$ & $4.0 \pm 0.39^{b}$ & $4.0 \pm 0.38^{\mathrm{d}}$ & $175 \pm 25^{\mathrm{e}}$ & $203 \pm 23$ \\
\hline Dose effect ${ }^{2}$ & \multicolumn{2}{|c|}{$p<0.0001$} & \multicolumn{2}{|c|}{$p<0.0110$} \\
\hline
\end{tabular}

\footnotetext{
${ }^{1}$ The oils were administered daily in a volume equal to $0.5 \%$ body weight for 13 weeks.

2 2-Way ANOVA (no significant dose $\times$ sex interaction).

FO, fish oil; ${ }^{\mathrm{a}} p<0.0006,{ }^{\mathrm{b}} p<0.0010,{ }^{\mathrm{c}} p<0.0246,{ }^{\mathrm{d}} p<0.0326,{ }^{\mathrm{f}} p<0.0035,{ }^{\mathrm{g}} p<0.0271$.

The values are $\mathrm{M} \pm \mathrm{SD}$ of $19-20$ rats.
}

Table 5. Concentrations of serum triglycerides, total cholesterol and high density lipoprotein.

\begin{tabular}{|c|c|c|c|c|c|c|}
\hline \multirow{2}{*}{$\begin{array}{c}\text { Treatment }^{1} \\
(\mathrm{~mL} \text { of } \mathrm{FO} / \mathrm{kg} / \mathrm{d})\end{array}$} & \multicolumn{2}{|c|}{$\mathrm{TG}(\mathrm{mg} / 100 \mathrm{~mL})$} & \multicolumn{2}{|c|}{$\mathrm{TCh}(\mathrm{mg} / 100 \mathrm{~mL})$} & \multicolumn{2}{|c|}{$\mathrm{HDL}(\mathrm{mg} / 100 \mathrm{~mL})$} \\
\hline & Male & Female & Male & Female & Male & Female \\
\hline 0.00 (corn oil control $)$ & $85 \pm 36$ & $86 \pm 40$ & $49 \pm 9$ & $59 \pm 15$ & $40 \pm 9$ & $54 \pm 14$ \\
\hline 0.10 & $95 \pm 45$ & $83 \pm 43$ & $50 \pm 9$ & $57 \pm 12$ & $41 \pm 8$ & $54 \pm 10$ \\
\hline 0.50 & $102 \pm 43$ & $74 \pm 37$ & $51 \pm 7$ & $57 \pm 16$ & $41 \pm 7$ & $55 \pm 12$ \\
\hline 2.50 & $89 \pm 47$ & $78 \pm 35$ & $45 \pm 6$ & $51 \pm 9$ & $36 \pm 6$ & $50 \pm 12$ \\
\hline 5.00 (menhaden oil) & $89 \pm 31$ & $62 \pm 23$ & $47 \pm 11$ & $44 \pm 10^{\mathrm{b}}$ & $34 \pm 10^{d}$ & $42 \pm 12^{\mathrm{f}}$ \\
\hline $5.00\left(\mathrm{MaxEPA}^{\mathbb{(})} \mathrm{oil}\right)$ & $86 \pm 41$ & $64 \pm 24$ & $43 \pm 6^{\mathrm{a}}$ & $46 \pm 9^{c}$ & $32 \pm 7^{\mathrm{e}}$ & $44 \pm 10^{\mathrm{g}}$ \\
\hline Dose effect ${ }^{2}$ & \multicolumn{2}{|c|}{ NS } & \multicolumn{2}{|c|}{$p<0.0002$} & \multicolumn{2}{|c|}{$p<0.0002$} \\
\hline
\end{tabular}

${ }^{1}$ The oils were administered daily in a volume equal to $0.5 \%$ body weight for 13 weeks.

${ }^{2}$ By two-way ANOVA.

NS, statistically not significant; ${ }^{\mathrm{a}} p<0.0311,{ }^{\mathrm{b}} p<0.0028,{ }^{\mathrm{c}} p<0.0152,{ }^{\mathrm{d}} p<0.0245,{ }^{\mathrm{e}} p<0.0026,{ }^{\mathrm{f}} p<0.0002,{ }^{\mathrm{g}} p<0.0003$.

The values are $\mathrm{M} \pm \mathrm{SD}$ of 19-20 rats. FO, fish oil. TG, triglycerides. Tch, total cholesterol. HDL, high density lipoprotein.

of fish oil intake. While serum chloride concentration was slightly elevated in the high-dose male rats, serum phosphorus level was slightly reduced in the highest dose of MO treated female rats (Table 8). The dose effect, as determined by two-way ANOVA, was statistically significant. The data on serum levels of iron and vitamin $\mathrm{E}$ show a significant decrease primarily in female rats (Table 8). To examine the overall dose response of the variables mentioned in this study, a linear correlation between dose levels and the variables was performed, and the data are summarized in Table 9. The following parameters were similarly affected in both sexes: relative liver weight, RDW, MPV, OFRBC, serum phosphorous, vitamin $\mathrm{E}$ and HDL. The histochemical analysis of the liver peroxisomes (CAT enzyme) showed no sign of peroxisomal proliferation (data not shown).

\section{DISCUSSION}

Our study of FOC was designed with dosing solutions with parameters similar to those used by other investigators (31) who based their studies on the $n-3 / n-6$ ratios (Table 1). These values were similar to the fish oil values in the dosing solutions, and we used the actual amount of fish oil for the statistical analysis rather than the ratios of the fish oil components. During the course of the study, the EPA and DHA concentrations of the dosing solutions as well as the FA profile of the oils were monitored along with their peroxide values (PV) to ensure the use of homogeneous and stable doses throughout.

It is known that rats treated with fish oil tend to spill food (32). In our study this was observed in the highdose groups (Table 3). Although food consumption was significantly higher in the high-dose groups, little or no difference was observed in average weekly weight gain, the female rats on high-doses of MO excepted. These animals gained about $2 \mathrm{~g} / \mathrm{wk}$ more than the control group. Although this small weight gain was statistically significant $(p<0.0057)$, it seems unlikely that this factor affected the outcome of this study. In fact, the twoway ANOVA showed no significant dose effect on weight gain despite a highly significant effect on apparent food consumption (Table $3, p<0.0005$ ). The data presented in Tables 4 to 9 , cannot be explained by factors other than our treatment.

Similar to the results of our earlier study with MaxEPA $^{\circledR}$, the relative liver and spleen weights were significantly elevated with the highest doses of FOC (Table 
Table 6. Some hematological data.

\begin{tabular}{|c|c|c|c|c|c|c|}
\hline $\begin{array}{c}\text { Treatment }^{1} \\
(\mathrm{~mL} \text { of } \mathrm{FO} / \mathrm{kg} / \mathrm{d})\end{array}$ & Male & Female & Male & Female & Male & Female \\
\hline & \multicolumn{2}{|c|}{$\mathrm{PT}(\mathrm{s})$} & \multicolumn{2}{|c|}{$\mathrm{aPTT}(\mathrm{s})$} & \multicolumn{2}{|c|}{ OFRBC (\%) } \\
\hline 0.00 (corn oil control) & $11 \pm 0.4$ & $10 \pm 0.4$ & $17 \pm 5$ & $16 \pm 3$ & $72 \pm 11$ & $83 \pm 11$ \\
\hline 0.10 & $10 \pm 0.6$ & $10 \pm 0.7$ & $16 \pm 1$ & $17 \pm 3$ & $76 \pm 13$ & $82 \pm 14$ \\
\hline 0.50 & $11 \pm 0.3$ & $10 \pm 0.8$ & $16 \pm 2$ & $18 \pm 3$ & $73 \pm 12$ & $84 \pm 9$ \\
\hline 2.50 & $11 \pm 0.6$ & $11 \pm 0.7$ & $18 \pm 7$ & $18 \pm 3$ & $69 \pm 15$ & $82 \pm 10$ \\
\hline 5.00 (menhaden oil) & $11 \pm 0.8$ & $10 \pm 0.6$ & $15 \pm 2$ & $17 \pm 2$ & $67 \pm 14$ & $74 \pm 15$ \\
\hline $5.00\left(\mathrm{MaxEPA}^{\circledR} \mathrm{oil}\right)$ & $11 \pm 0.4$ & $10 \pm 0.5$ & $15 \pm 2$ & $17 \pm 2$ & $69 \pm 16$ & $79 \pm 10$ \\
\hline \multirow[t]{2}{*}{ Dose effect ${ }^{2}$} & \multicolumn{2}{|c|}{ NS } & \multicolumn{2}{|c|}{ NS } & \multicolumn{2}{|c|}{$p<0.0479$} \\
\hline & \multicolumn{2}{|c|}{$\operatorname{WBC}\left(10^{3} / \mathrm{mm}^{3}\right)$} & \multicolumn{2}{|c|}{ MPV (fL) } & \multicolumn{2}{|c|}{ RDW (\%) } \\
\hline 0.00 (corn oil control) & $13.4 \pm 3$ & $9.4 \pm 2$ & $8.5 \pm 0.6$ & $8.2 \pm 0.6$ & $14 \pm 0.6$ & $12 \pm 0.6$ \\
\hline 0.10 & $12.5 \pm 4$ & $9.3 \pm 2$ & $8.4 \pm 1.4$ & $8.0 \pm 0.7$ & $14 \pm 0.8$ & $13 \pm 0.9$ \\
\hline 0.50 & $12.5 \pm 3$ & $9.4 \pm 3$ & $8.2 \pm 0.6$ & $8.1 \pm 0.6$ & $15 \pm 0.7$ & $13 \pm 0.8$ \\
\hline 2.50 & $14.7 \pm 4$ & $10.0 \pm 3$ & $7.7 \pm 0.7^{\mathrm{a}}$ & $7.4 \pm 0.9^{\mathrm{d}}$ & $15 \pm 0.5$ & $13 \pm 0.9$ \\
\hline 5.00 (menhaden oil) & $15.1 \pm 2$ & $10.4 \pm 2$ & $7.6 \pm 0.6^{b}$ & $7.2 \pm 0.4^{\mathrm{e}}$ & $15 \pm 1.3^{f}$ & $13 \pm 0.6^{\mathrm{h}}$ \\
\hline $5.00\left(\mathrm{MaxEPA}^{(}{ }^{(} \mathrm{oil}\right)$ & $14.7 \pm 3$ & $10.9 \pm 2$ & $7.9 \pm 0.7^{c}$ & $7.1 \pm 0.6^{\mathrm{e}}$ & $15 \pm 0.8^{8}$ & $13 \pm 1.5^{\mathrm{i}}$ \\
\hline Dose effect ${ }^{2}$ & \multicolumn{2}{|c|}{$p<0.0056$} & \multicolumn{2}{|c|}{$p<0.0002$} & \multicolumn{2}{|c|}{$p<0.0002$} \\
\hline
\end{tabular}

${ }^{1}$ The oils were administered daily in a volume equal to $0.5 \%$ body weight for 13 weeks.

${ }^{2}$ By two-way ANOVA.

NS, statistically not significant; ${ }^{\mathrm{a}} p<0.0044,{ }^{\mathrm{b}} p<0.0029,{ }^{\mathrm{c}} p<0.0469,{ }^{\mathrm{d}} p<0.0009,{ }^{\mathrm{e}} p<0.0002,{ }^{\mathrm{f}} p<0.0014,{ }^{\mathrm{g}} p<0.0379$, ${ }^{\mathrm{h}} p<0.0004,{ }^{\mathrm{i}} \mathrm{p}<0.0003$.

The values are $\mathrm{M} \pm \mathrm{SD}$ of 17-20 rats. FO, fish oil. PT, prothrombin time. aPTT, activated partial thromboplastin time. OFRBC, omotic fragility of red blood cells. WBC, white blood cell count. MPV, mean platelet volume. RDW, red blood cell distribution width.

Table 7. Clinical chemistry data.

\begin{tabular}{|c|c|c|c|c|c|c|}
\hline $\begin{array}{c}\text { Treatment }^{1} \\
(\mathrm{~mL} \text { of } \mathrm{FO} / \mathrm{kg} / \mathrm{d})\end{array}$ & Male & Female & Male & Female & Male & Female \\
\hline & \multicolumn{2}{|c|}{ BUN (mg/dL) } & \multicolumn{2}{|c|}{ Creat. $(\mu \mathrm{g} / \mathrm{dL})$} & \multicolumn{2}{|c|}{ BUN/Creat. Ratio } \\
\hline 0.00 (corn oil control) & $13.8 \pm 2$ & $15.4 \pm 2$ & $680 \pm 130$ & $675 \pm 80$ & $20.8 \pm 4$ & $23.1 \pm 4$ \\
\hline 0.10 & $14.0 \pm 2$ & $16.2 \pm 2$ & $639 \pm 80$ & $635 \pm 110$ & $22.4 \pm 5$ & $26.8 \pm 9$ \\
\hline 0.50 & $14.0 \pm 2$ & $16.7 \pm 3$ & $635 \pm 90$ & $615 \pm 170$ & $22.6 \pm 5$ & $30.0 \pm 13$ \\
\hline 2.50 & $13.6 \pm 2$ & $17.1 \pm 3$ & $605 \pm 180$ & $590 \pm 190^{b}$ & $24.3 \pm 8$ & $32.8 \pm 16^{\mathrm{e}}$ \\
\hline 5.00 (menhaden oil) & $14.9 \pm 2$ & $18.2 \pm 4^{\mathrm{a}}$ & $620 \pm 160$ & $616 \pm 80^{c}$ & $25.7 \pm 9$ & $30.1 \pm 10^{f}$ \\
\hline $5.00\left(\mathrm{MaxEPA}^{\circledR}\right.$ oil $)$ & $14.4 \pm 2$ & $16.1 \pm 2$ & $645 \pm 110$ & $585 \pm 60^{\mathrm{d}}$ & $22.7 \pm 5$ & $27.7 \pm 5^{\mathrm{g}}$ \\
\hline \multirow[t]{2}{*}{ Dose effect ${ }^{2}$} & \multicolumn{2}{|c|}{$p<0.0222$} & \multicolumn{2}{|c|}{ NS } & \multicolumn{2}{|c|}{$p<0.0093$} \\
\hline & \multicolumn{2}{|c|}{ SGOT (IU/L) } & \multicolumn{2}{|c|}{ SGOT/SGPT Ratio } & \multicolumn{2}{|c|}{ Total LDH (U/L) } \\
\hline 0.00 (corn oil control) & $122 \pm 35$ & $143 \pm 63$ & $1.9 \pm 0.4$ & $2.0 \pm 0.7$ & $756 \pm 312$ & $588 \pm 339$ \\
\hline 0.10 & $133 \pm 48$ & $143 \pm 82$ & $1.6 \pm 0.5^{\mathrm{i}}$ & $2.1 \pm 0.6$ & $862 \pm 599$ & $595 \pm 409$ \\
\hline 0.50 & $130 \pm 42$ & $109 \pm 34$ & $1.5 \pm 0.4^{j}$ & $2.0 \pm 0.5$ & $950 \pm 674$ & $389 \pm 168$ \\
\hline 2.50 & $104 \pm 34^{\mathrm{h}}$ & $123 \pm 55$ & $1.5 \pm 0.3^{\mathrm{k}}$ & $2.0 \pm 0.5$ & $560 \pm 404^{\mathrm{n}}$ & $491 \pm 309$ \\
\hline 5.00 (menhaden oil $)$ & $113 \pm 30$ & $113 \pm 55$ & $1.3 \pm 0.3^{1}$ & $1.8 \pm 0.3$ & $564 \pm 421^{\circ}$ & $407 \pm 251$ \\
\hline $5.00\left(\mathrm{MaxEPA}^{(\mathbb{P})} \mathrm{oil}\right)$ & $127 \pm 46$ & $130 \pm 51$ & $1.6 \pm 0.3^{\mathrm{m}}$ & $2.0 \pm 0.5$ & $673 \pm 542$ & $610 \pm 400$ \\
\hline Dose effect ${ }^{2}$ & \multicolumn{2}{|c|}{$p<0.0117$} & \multicolumn{2}{|c|}{ NS } & \multicolumn{2}{|c|}{ NS } \\
\hline
\end{tabular}

\footnotetext{
${ }^{1}$ The oils were administered daily in a volume equal to $0.5 \%$ body weight for 13 weeks. FO, fish oil.

${ }^{2}$ By two-way ANOVA.
}

NS, statistically not significant; ${ }^{\mathrm{a}} p<0.0028,{ }^{\mathrm{b}} p<0.0351,{ }^{\mathrm{c}} p<0.0452,{ }^{\mathrm{d}} p<0.0390,{ }^{\mathrm{e}} p<0.0018,{ }^{\mathrm{f}} p<0.0006,{ }^{\mathrm{g}} p<0.0093$, ${ }^{\mathrm{h}} p<0.0229,{ }^{\mathrm{i}} p<0.0126,{ }^{\mathrm{j}} p<0.0039,{ }^{\mathrm{k}} p<0.0009,{ }^{\mathrm{l}} p<0.0002,{ }^{\mathrm{m}} p<0.0096,{ }^{\mathrm{n}} p<0.0390,{ }^{\circ} p<0.0081$.

The values are $\mathrm{M} \pm \mathrm{SD}$ of $17-20$ rats. BUN, blood urea nitrogen. Creat., serum creatinine. SGOT, serum glutamic oxaloacetate transaminase. SGPT. serum glutamic pyruvic transaminase. LDH, serum lactic dehydrogenase. 
Table 8. Serum levels of some minerals and vitamin E.

\begin{tabular}{|c|c|c|c|c|}
\hline $\begin{array}{c}\text { Treatment }^{1} \\
(\mathrm{~mL} \text { of } \mathrm{FO} / \mathrm{kg} / \mathrm{d})\end{array}$ & Male & Female & Male & Female \\
\hline & \multicolumn{2}{|c|}{ Chloride (mм/L) } & \multicolumn{2}{|c|}{ Phosphorous (mg/100 mL) } \\
\hline 0.00 (corn oil control) & $94.7 \pm 2.0$ & $95.3 \pm 2.7$ & $11.5 \pm 1.3$ & $9.5 \pm 1.1$ \\
\hline 0.10 & $94.5 \pm 3.1$ & $96.5 \pm 3.0$ & $11.0 \pm 1.3$ & $9.3 \pm 0.9$ \\
\hline 0.50 & $95.8 \pm 2.6$ & $97.5 \pm 2.6$ & $11.5 \pm 1.6$ & $8.9 \pm 1.0$ \\
\hline 2.50 & $95.4 \pm 2.3$ & $96.9 \pm 2.8$ & $11.0 \pm 1.1$ & $9.4 \pm 1.4$ \\
\hline 5.00 (menhaden oil) & $96.4 \pm 2.6^{\mathrm{a}}$ & $97.6 \pm 2.7$ & $10.6 \pm 1.4$ & $8.6 \pm 0.8^{c}$ \\
\hline $5.00\left(\mathrm{MaxEPA}^{\circledR} \mathrm{oil}\right)$ & $97.0 \pm 2.6^{b}$ & $97.0 \pm 3.5$ & $10.7 \pm 1.1$ & $9.1 \pm 1.1$ \\
\hline \multirow[t]{2}{*}{ Dose effect ${ }^{2}$} & \multicolumn{2}{|c|}{$p<0.0028$} & \multicolumn{2}{|c|}{$p<0.0216$} \\
\hline & \multicolumn{2}{|c|}{ Iron $(\mu \mathrm{g} / 100 \mathrm{~mL})$} & \multicolumn{2}{|c|}{ Vitamin E (mg/L) } \\
\hline 0.00 (corn oil control) & $247 \pm 37$ & $475 \pm 95$ & $13.7 \pm 3.2$ & $20.4 \pm 5.4$ \\
\hline 0.10 & $238 \pm 28$ & $461 \pm 106$ & $15.2 \pm 5.5$ & $20.8 \pm 5.8$ \\
\hline 0.50 & $236 \pm 25$ & $473 \pm 99$ & $4.5 \pm 3.5$ & $20.3 \pm 6.8$ \\
\hline 2.50 & $247 \pm 37$ & $365 \pm 80^{d}$ & $12.9 \pm 3.8$ & $16.3 \pm 6.9^{\mathrm{h}}$ \\
\hline 5.00 (menhaden oil) & $240 \pm 41$ & $363 \pm 92^{\mathrm{d}}$ & $9.7 \pm 2.7^{f}$ & $10.5 \pm 3.5^{\mathrm{i}}$ \\
\hline $5.00\left(\mathrm{MaxEPA}^{\circledR} \mathrm{oil}\right)$ & $231 \pm 36$ & $388 \pm 55^{\mathrm{e}}$ & $11.4 \pm 3.2^{\mathrm{g}}$ & $12.5 \pm 3.1^{\mathrm{i}}$ \\
\hline Dose effect ${ }^{2}$ & \multicolumn{2}{|c|}{$p<0.0002$} & \multicolumn{2}{|c|}{$p<0.0002$} \\
\hline
\end{tabular}

${ }^{1}$ The oils were administered daily in a volume equal to $0.5 \%$ body weight for 13 weeks.

${ }^{2}$ By two-way ANOVA.

FO, fish oil; ${ }^{\mathrm{a}} p<0.0281,{ }^{\mathrm{b}} p<0.0035,{ }^{\mathrm{c}} p<0.0109,{ }^{\mathrm{d}} p<0.0003,{ }^{\mathrm{e}} p<0.0029,{ }^{\mathrm{b}} p<0.0012,{ }^{\mathrm{g}} p<0.0512,{ }^{\mathrm{b}} p<0.0183$, ${ }^{\mathrm{i}} p<0.0002$.

The values are $\mathrm{M} \pm \mathrm{SD}$ of $18-20$ rats.

Table 9. Regression of some variables on the gavaged dose levels.

\begin{tabular}{|c|c|c|c|c|}
\hline \multirow{2}{*}{ Variables } & \multicolumn{2}{|c|}{ Male } & \multicolumn{2}{|c|}{ Female } \\
\hline & $r^{1}=$ & $p<$ & $r^{1}=$ & $p<$ \\
\hline Liver $(\mathrm{g} / 100 \mathrm{~g} \text { Bwt. })^{2}$ & 0.311 & 0.0017 & 0.375 & 0.0002 \\
\hline Spleen (mg/100 g Bwt.) & NS & NS & 0.342 & 0.0006 \\
\hline Gonads (mg/100 g Bwt.) & NS & NS & 0.340 & 0.0007 \\
\hline BUN $(\mathrm{mg} / 100 \mathrm{~mL})$ & NS & NS & 0.280 & 0.0051 \\
\hline BUN/Creatinine ratio & 0.254 & 0.0123 & NS & NS \\
\hline Uric acid (mg/100 mL) & NS & NS & -0.240 & 0.0169 \\
\hline MCHC $(\%)$ & 0.224 & 0.0320 & NS & NS \\
\hline WBC count $\left(10^{3} / \mathrm{mm}^{3}\right)$ & 0.286 & 0.0058 & NS & NS \\
\hline RDW (\%) & 0.382 & 0.0003 & 0.332 & 0.0013 \\
\hline MPV (fL) & -0.362 & 0.0005 & -0.478 & 0.0002 \\
\hline OFRBC (\%) & -0.196 & 0.0506 & -0.253 & 0.0117 \\
\hline APase $(\mathrm{IU} / \mathrm{L})^{3}$ & 0.221 & 0.0297 & NS & NS \\
\hline $\mathrm{LDH}(\mathrm{U} / \mathrm{L})^{3}$ & -0.245 & 0.0156 & NS & NS \\
\hline SGOT/SGPT ratio & -0.365 & 0.0003 & NS & NS \\
\hline Chloride $(\mathrm{mm} / \mathrm{L})^{3}$ & 0.228 & 0.0250 & NS & NS \\
\hline Calcium $(\mathrm{mg} / 100 \mathrm{~mL})^{3}$ & 0.292 & 0.0039 & NS & NS \\
\hline Phosophorous $(\mathrm{mg} / 100 \mathrm{~mL})^{3}$ & -0.215 & 0.0344 & -0.203 & 0.0441 \\
\hline Iron $(\mu \mathrm{g} / 100 \mathrm{~mL})^{3}$ & NS & NS & -0.444 & 0.0002 \\
\hline Vitamin $\mathrm{E}(\mu \mathrm{g} / 100 \mathrm{~mL})^{3}$ & -0.433 & 0.0002 & -0.565 & 0.0002 \\
\hline Cholesterol $(\mathrm{mg} / 100 \mathrm{~mL})^{3}$ & NS & NS & -0.342 & 0.0006 \\
\hline $\mathrm{HDL}(\mathrm{mg} / 100 \mathrm{~mL})^{3}$ & -0.327 & 0.0012 & -0.437 & 0.0002 \\
\hline Triglycerides $(\mathrm{mg} / 100 \mathrm{~mL})^{3}$ & NS & NS & -0.200 & 0.0474 \\
\hline
\end{tabular}

\footnotetext{
${ }^{1}$ Correlation coefficient.

${ }^{2}$ Bwt., body weight.

${ }^{3}$ In serum; BUN, blood urea nitrogen. MCHC, mean cell hemoglobin concentration. WBC, white blood cell count. RDW, red blood cell distribution width. MPV, mean platelet volume. OFRBC, osmotic fragility of red blood cells. APase, alkaline phosphatase. LDH, lactic dehydrogenase. SGOT, serum glutamic oxaloacetate transaminase. SGPT, serum glutamic pyruvic transaminase. HDL, high density lipoprotein.

NS, statistically not significant.
} 
4). In the human population, hepatosplenomegaly has been reported as a result of nutritional zinc deficiency (33). Although we did not assess the mineral status of animals, it is possible that a mild zinc deficiency linked to decreased mineral absorption was caused by high fish oil intake. Enlargement of the liver and spleen in our study did not appear to be as severe as that observed in human zinc deficiency. In any event, the pathological examinations of these organs failed to provide adequate morphological and/or other information to explain the increase in relative organ weights. An accurate test of peroxisomal proliferation would have been useful in explaining the increase in relative organ weight (34). However, in a recent report on mice treated with fish oil for 30 days, a $40 \%$ increase in spleen size was observed when compared to the soybean oil control group (35). This confirms our finding on enlagement of spleen size in rats as a result of treatment with Menhaden oil (Table 4). A significant increase in the concentration of RBC phosphatidylcholine hydroperoxide as well as phosphatidyl-ethanolamine hydroperoxide was also found in the mice treated with fish oil (35). The histopathological data on most of the tissues we examined were unremarkable.

In the present study, a 23 to $26 \%$ reduction in serum TG was observed in the high-dose female groups. Statistically, this reduction was not significant (Table 5). A study of 19 healthy human volunteers who received $6 \mathrm{~g} / \mathrm{d}$ of MaxEPA fish oil for 21 days also showed no significant change in serum TG (36). In contrast, other investigators have reported a significant reduction in serum TG in miniature pigs treated with fish oil (37), in hypertriglyceridemic subjects receiving PUFA (38) and in female rats treated with MaxEPA in an amount equal to $0.5 \%$ body weight, 5 days a week for $13 \mathrm{wk}(23)$. Moreover, a recent review on the subject (39) revealed a dose response decrease in blood TG levels in hypertriglyceridemic patients receiving high doses of fish oil supplements which persisted as long as supplementation continued. Although the values for female rats were within the reported normal range (40), the negative correlations between dose levels and serum TG were significant in this study (Table 9) and in our previous study (23) which confirms the TG-lowering effect of fish oil in female rats. The total cholesterol values were within the reported normal range $(40)$ but were significantly reduced $(22 \%)$ by treatment with the high doses of fish oil (Table 5). These data support the findings by others who found significant reduction in serum cholesterol caused by fish oil ingestion (41), possibly through increased cholesterol secretion into bile (42). However, this was associated with a significant reduction $(22 \%)$ in absolute amount of serum HDL level as well (Table 5). The two-way ANOVA indicates highly significant dose effect in reducing serum cholesterol and HDL $(p<0.0002)$. In fact, the HDL-lowering effect of dietary fish oil or $n-3$ fatty acids has been reported in rats (43), hamsters (44), pigs (45) and monkeys (46). However, review of literature revealed that in humans fish oil consumption may actually increase serum HDL level $(47,48)$.

Fish oil consumption is known to increase bleeding time in rabbits (49) and in humans (12). While we did not directly measure this variable, our results of PT and aPTT (Table 6), two factors involved in blood clotting, indicated no treatment effect. These results agree with those obtained from a study with human subjects who received $6 \mathrm{~g} \mathrm{DHA} / \mathrm{d}$ for 90 days (50) and confirm our previous findings (23) that fish oil consumption in rats had no effect on these parameters. The OFRBC in females however, was reduced by $9 \%$. We can not explain this sex difference in the susceptibility to changes in OFRBC after fish oil treatment. Nevertheless, there was a weak, but significant, correlation between dose levels and OFRBC in both sexes as indicated in Table 9. A possible explanation for this finding is provided by the reports that the ingested $n-3$ FA can be incorporated into the cell membrane (51) causing higher membrane fluidity, greater flexibility of the cell membrane and increased resistance to osmotic pressure. When rats were fed a diet containing 10\% salmon oil for 3 weeks, their erythrocytes became osmotically less resistant to $\mathrm{NaCl}$ solutions when compared to rats on a $10 \%$ coconut oil diet (52). Erythrocytes obtained from healthy human volunteers receiving $7.7 \mathrm{~g}$ of $n-3 \mathrm{FA} / \mathrm{d}$ for 180 days showed, among other observations, a decrease in susceptibility to osmotic hemolysis (53). The authors concluded that high doses of n-3 FA can modify erythrocytes' structure and function with resultant harmful side effects.

High doses of FOC increased the leukocyte count from $10 \%$ (male rats, MaxEPA ${ }^{\circledR}$ ) to $16 \%$ (female rats, MaxEPA $^{\circledR}$ ). Although this increase was statistically insignificant, the pooled data on both sexes showed a highly significant dose effect $(p<0.0056$, Table 6). There was a small but highly significant correlation coefficient between the two variables in male rats only $(p<0.0058$, Table 9). The elevated WBC count may be a response to high doses of FOC. However, values in the control and treated female rats were within the reported normal range of 6.6-12.6 but in male rats were beyond the reported normal range of $8-11.8 \times$ $10^{3} / \mathrm{mm}^{3}$ of blood (54). Although the platelet count showed no treatment effect (data not shown), the MPV was significantly decreased even at the medium dose levels and in both sexes (Table 6). The pooled male and female data showed a highly significant dose effect on MPV $(p<0.0002)$. Our finding is in agreement with a recent report on rats (55) but contrary to the results obtained from a human study (56). This latter study showed that when 266 healthy volunteers received $15 \mathrm{~mL} / \mathrm{d}$ of cod liver oil/olive oil or whale oil for 12 weeks, their MPV values were elevated by $8 \%$. This discrepancy may be explained by different administered dose levels to two different species and for different duration.

Another structural change in blood cells of rats treated with high doses of fish oil was a significant increase in RDW in both sexes (Table 6). It may be speculated that this was a compensatory response to a subtle 
hemolysis, as evidenced by enlarged spleen (Table 4), and/or to a diminished intestinal iron absorption caused by high level ingestion of PUFA. In fact, this may be supported by another finding, e.g. a decrease in serum iron, especially in the high-dose female rats (Tables 8 and 9). Increase in the RDW rate has been reported in infant anemia (57) and in $\alpha$-thalassemia (58). However, we found no sign of anemia in the FOC treated animals, and we cannot explain with certainity the underlying mechanism and biological consequences of this observation on RDW.

In our study (Table 7), blood urea nitrogen (BUN) was elevated by $8 \%$ in male (statistically not significant) and $18 \%$ in female rats $(p<0.0028)$. Since in rats, BUN level does not appear to vary with sex or age (59), we cannot explain the sex difference in BUN response to high doses of FOC. In humans with acute renal failure, the BUN level can be used as an indicator of protein catabolism (60). Although the BUN values in our study were within the reported normal range (46), the pathology data did not show kidney and/or renal tubular damage, which may have accounted for the high level of BUN in female rats $(p<0.0222)$. However, as indicated in Table 4, the high-dose treated female rats exhibited an $8.5 \%$ increase in relative liver weight. This may partially explain the increase in their BUN level. Creatinine is a product of muscle metabolism, and its serum levels are directly related to muscular conditioning. According to Everett and Harrison (61), factors that increase serum creatinine levels will also elevate the BUN levels. The data presented in Table 7 contradict this conclusion by Everett and Harrison because the BUN level slightly increased in high-dose groups, while the serum creatinine levels significantly decreased $(p<0.0390)$. The animals on high doses of FOC were more sedentary, thus rendering lower serum creatinine levels. It is important to note that the BUN/Creatinine ratios were significantly increased in the high dose groups of female and that the overall dose effect on the ratio of these variables was highly significant (Table 7 , $p<0.0093)$. In any event, all the BUN and creatinine values presented in Table 7 were within the normal range reported in the literature (54), and these changes may be considered biologically insignificant. There was a significant dose effect on the SGOT values $(p<0.0117)$. Also the SGOT/SGPT ratios were reduced at all dose levels. However, the SGOT values were beyond the average values reported in the literature (54) making it difficult to interpret the data. Likewise, the data on serum total $\mathrm{LDH}$ are directionally inconsistent.

The blood electrolyte data show that serum chloride values increased significantly (MO, $p<0.0281$ and MaxEPA $^{\circledR}, p<0.0035$, Table 8) with high doses of fish oil in male rats. However, these values were below those reported in the normal range (54). In our study, the overall dose effect in the pooled male and female data was highly significant ( $p<0.0028$ ). Wickwire et al. (62) reported accelerated renal disease in rats fed a $9 \% \mathrm{MO}$ diet; Tateno et al. (63) reported a BSA-induced immune complex nephritis in mice fed a casein-based diet con- taining 10\% fish oil concentrate. Therefore, in conjunction with the observed increase in BUN/Creatinine ratio (Table 7), further investigation is warranted on the effects of long-term, high-dose intake of fish oil concentrates on renal function. As shown in Table 8, a modest reduction in serum phosphorous level was observed in the high-dose female rats $(p<0.0109)$. The pooled male and female data also showed a significant dose effect $(p<0.0216)$. However, our values seem to be within the upper limits of the reported normal range (54), and it probably should be considered a statistical aberration without biological significance.

Our data showed that FOC lowered serum iron level in female rats by $34 \%$ (Table 8 ). We are unable to explain the apparent suceptibility of serum iron in female rats to FOC, but this finding confirmed our previous study (23). However, in the present study, the serum iron values in both sexes were above the reported normal values (54). In humans, a daily intake of $20 \mathrm{~mL}$ of FOC in both sexes for ten weeks resulted in a significant reduction in serum and erythrocyte selenium concentrations (64). Rats receiving sardine oil for 4 weeks, showed a significant reduction in dietary iron absorption and retention (65). Another potentially harmful effect of high doses of FOC was a $48 \%$ reduction in serum vitamin $\mathrm{E}$ level in female rats and a $17 \%$ reduction in male rats both of which were statistically significant (Table 8). The overall dose effect on both parameters, serum iron and vitamin $\mathrm{E}$, were highly significant $(p<0.0002)$. These findings are in agreement with the report of a significant decrease in both serum and liver concentration of vitamin $\mathrm{E}$ when rats were fed diets high in FOC (66). Likewise, our earlier studies showed that gavaging MaxEPA ${ }^{\circledR}$ to rats (23) or feeding MO to miniature swine $(67)$ resulted in a significant reduction in vitamin $\mathrm{E}$ levels in serum and in liver, respectively.

High levels of dietary polyunsaturated fatty acids (PUFA) appears to reduce the intestinal absorption of iron (Table 8) while increasing the body's demand for vitamin $\mathrm{E}(68,69)$. It must be noted that all the oils used in this study were adequately and equally fortified with both TBHQ and vitamin E. It is possible that the vitamin $\mathrm{E}$ intake was either inadequate and/or not absorbed in amounts sufficient to compensate for the additional burden imposed on the antioxidant system of the animals by the high intake of PUFA, leading to reduced body store of vitamin $\mathrm{E}$.

The dose response of some variables are presented in Table 9. Negative control groups for both sexes to eliminate possible oil effect were not included in the study. Although some of the $p$ values were highly significant, the overall correlation coefficients were small and the effects were apparent mostly at the highest dose levels. Nevertheless, some of these changes may be biologically significant. The positive correlations between dose levels and relative organ size and RDW may be considered unwanted side effects of consumption of high quantities of fish oil concentrates. Likewise, with the exceptions of OFRBC and serum phosphorous levels, all the negative correlations between dose levels and other parameters 
were highly significant. That included serum iron in female rats $(r=-0.444, p<0.0002)$ and serum vitamin $\mathrm{E}$ and absolute amount of HDL concentrations in both sexes.

While long-term administration of high doses of fish oil had little or no effect on the average weekly weight gain of the rats, it caused a significant increase in relative liver and spleen weights. The mean platelet volume and osmotic fragility of red blood cells were reduced which indicates an effect on biological membrane structure and possibly on membrane functions. This study, as well as the previous study on $\mathrm{MaxEPA}^{\circledR}$, appears to confirm some beneficial effects of fish oil consumption in the reduction of total serum cholesterol level in male and female rats. However, as a concomitant reduction in the serum HDL levels was seen as well, the benefit of this effect should be interpreted and extrapolated to humans with extreme caution. An important finding, not reported by others, was the adverse effect of fish oil on total serum iron in female rats. In confirmation of reports by others and by us, we also observed a significant reduction in serum vitamin $\mathrm{E}$ levels in male and female rats treated with the high doses of fish oils concentrates. We conclude that rats, especially females, given subchronic and high doses of FOC develop potentially harmful changes in several biochemical indices. These include increased red cell deformity, increased relative liver and spleen weights, and reduced MPV, absolute amount of serum HDL, serum iron and serum vitamin $\mathrm{E}$ concentrations.

\section{Acknowledgment}

We thank Ms. C. Ford for performing all the PT and aPTT tests. We also thank Ms. A. NguyenPho for performing the FA profiles and the peroxide values for the dosing solutions.

\section{REFERENCES}

1) Herold MP, Kinsella EJ. 1986. Fish oil consumption and decreased risk of cardiovascular disease: A comparison of findings from animal and human feeding trials. $\mathrm{Am} \mathrm{J}$ Clin Nutr 43: 566-598.

2) Borge N, Refvem H. 1998. Use of fish oils appears to reduce infarct size as estimated from peak creatine kinase and lactate dehydrogenase activities. Cardiology 89: 94-102.

3) Kremer JM. 2000. n-3 Fatty acid supplements in rheumatoid arthritis. Am J Clin Nutr 71: 349S-351S.

4) Ziboh VA, Miller CC, Cho Y. 2000. Metabolism of polyunsaturated fatty acids by skin epidermal enzymes: generation of antiinflamatory and antiproliferative metabolites. Am J Clin Nutr 71: 361S-366S.

5) Hubbard NE, Lim D, Erickson KL. 1998. Alteration of murine mammary tumorigenesis by dietary enrichment with $n-3$ fatty acids in fish oil. Cancer Lett 124: $1-7$.

6) Kolanowski W, Swiderski F, Berger S. 1999. Possibilities of fish oil application for food products enrichment with omega-3 PUFA. Int J Food Sci Nutr 50: 39-49.

7) Rogers KA, Adelstein R. 1990. MaxEPA fish oil enhances cholesterol-induced intimal foam cell formation in rabbits. Am J Pathol 137: 945-951.
8) Ershoff BH. 1980. Effect of diet on fish oil toxicity in the rat. J Nutr 71: 45-53.

9) Knapp HR. 1990. Polyunsaturates, endogenous eicosanoids, and cardiovascular disease. J Am Coll Nutr 9: 344-351.

10) Thomas TR, Fischer BA, Kist WB, Horner KE, Cox RH. 2000. Effects of exercise and $n$-3 fatty acids on postprandial lipemia. J Appl Physiol 88: 2199-2204.

11) Peck MD. 1994. Omega-3 polyunsaturated fatty acids: benefit or harm during sepsis? New Horiz 2: 230-236.

12) Kromann N, Green A. 1980. Epidemiological studies in the Upernavik district, Greenland: Incidence of some chronic diseases, 1950-1974. Acta Med Scand 208: 401-406.

13) Chang HR, Dulloo AG, Vladoianu IR, Piguet PF, Arsenijevic D, Girardier L, Pechére JC. 1992. Fish oil decreases natural resistance of mice to infection with Salmonella typhimurium. Metabolism 41: 1-2.

14) Byleveld PM, Pang GT, Clancy RL, Roberts DCK. 1999. Fish oil feeding delays influenza virus clearance and impairs production of interferon- $\gamma$ and virus-specific immunoglobulin A in the lungs of mice. J Nutr 129: 328-335.

15) Morimoto $M$, Zern MA, Hagbjörk AL, IngelmanSundberg M, French SW. 1994. Fish oil, alcohol, and liver pathology: role of cytochrome P4502E1. Proc Soc Exp Biol Med 207: 197-205.

16) Kuralay F, Akarca US, Özutemiz Ö, Kutay F, Batur Y. 1998. Possible role of glutathione in prevention of acetaminophen-induced hepatotoxicity enhanced by fish oil in male Wistar rats. J Toxcol Environ Health A 53: 223-229.

17) Van Elswyk ME, Hargis BM, Williams JD, Hargis PS. 1994. Dietary menhaden oil contributes to hepatic lipidosis in laying hens. Poult Sci 73: 653-662.

18) Rogers KA, Karnovsky MJ. 1988. Dietary fish oil enhances monocyte adhesion and fatty streak formation in the hypercholesterolemic rats. Am J Path 132: $382-388$.

19) Falton CV, Crook D, Davis MJ, Oliver MF. 1994. Dietary polyunsaturated fatty acids and composition of human aortic plaques. Lancet 344: 1195-1196.

20) Malasanos TH, Stacpoole PW. 1991. Biological effects of $\omega-3$ fatty acids in diabetes mellitus. Diabetes Care 14: 1160-1179.

21) Berdanier CD, Johnson B, Hartle DK, Crowell W. 1992. Life span is shortened in BHE/cdb rats fed a diet containing $9 \%$ menhaden oil and $1 \%$ corn oil. J Nutr $\mathbf{1 2 2}$ : 1309-1317.

22) Stone NJ. 1996. Fish consumption, fish oil, lipids, and coronary heart disease. Circulation 94: 2337-2340.

23) Rabbani PI, Sheikh NM, Chirtel S, Jackson R, Ruffin G. 1999. Effects of long-term consumption of high-doses of fish oil concentrates on clinical parameters in male and female rats. J Nutr Sci Vitaminol 45: 553-565.

24) Anderson RL. 1987. Intestinal responses in the male rat to gavaged corn oil. Cancer Lett 36: 55-63.

25) Tsai CE, Wooten JT, Otto DA. 1989. Stability of fish oil in a purified diet with added antioxidants: Effects of temperature and light. Nutr Res 9: 673-679.

26) Einig RG, Ackman RG. 1987. w-3 PUFA in marine oil products. J Am Oil Chem 64: 499-502.

27) 1990. Peroxide value of oils and fats, titration method. In: Official Methods of Analysis of the Association of Official Analytical Chemists (Helrich K, ed), 15th ed, 
sec. 965.33, Vol II, p 956. AOAC, Arlington, VA.

28) Dacie JV, Lewis SM. 1968. Protocol Hematology, 4th ed., p 166-168. Grune and Stratton, New York.

29) Graham RC, Karnovsky MJ. 1966. The early stages of absorption of injected horseradish peroxidase in the proximal tubules of monkey kidney: ultrastructural cytochemistry by a new technique. J Histochem Cytochem 14: 291-302.

30) SAS Institute. 1985. SAS User's Guide: Statistics, 5th Ed. Statistical Analysis System (SAS) Institute, Cary, NC.

31) Wander RC, Hall JA, Gradin JL, Du S-H, Jewell DE. 1997. The ratio of dietary (n-6) to (n-3) fatty acids influences immune system function, eicosanoid metabolism, lipid peroxidation and vitamin E status in aged dogs. J Nutr 127: 1198-1205.

32) Halminski MA, Marsh JB, Harrison EH. 1991. Differential effects of fish oil, safflower oil and palm oil on fatty acid oxidation and glycerolipid synthesis in rat liver. J Nutr 121: 1554-1561.

33) Prasad AS, Halstead JA, Nadimi M. 1961. Syndrome of iron deficiency anemia, hepatosplenomegaly, hypogonadism, dwarfism and geophagia. Am J Med 31: $532-546$.

34) De Craemer D, Roels F, Vanden Branden C. 1993. Rapid effects of dietary fish oil on peroxisomes in mouse liver. Eur J Morphol 31: 77-81.

35) Oarada M, Furukawa H, Majima T, Miyazawa T. 2000. Fish oil diet affects on oxidative senescence of red blood cells linked to degeneration of spleen cells in mice. Biochim Biophys Acta 1487: 1-14.

36) Foulon T, Richard MJ, Payen N, Bourrain JL, Beani JC, Laporte F, Hadjian A. 1999. Effects of fish oil fatty acids on plasma lipids and lipoproteins and oxidant-antioxidant imbalance in healthy subject. Scand J Clin Lab Invest 59: 239-248.

37) Huff MW, Telford DE, Edmonds BW, McDonald CG, Evans AJ. 1993. Lipoprotein lipases, lipoprotein density gradient profile and LDL receptor activity in miniature pigs fed fish oil and corn oil. Biochim Biophys Acta 1210: 113-122.

38) Pownall HJ, Bruchi D, Kilinc C, Osmundsen K, Pao Q, Payton-Ross C, Gotto AM Jr, Ballantyne CM. 1999. Correlation of serum triglyceride and its reduction by omega- 3 fatty acids with lipid transfer activity and the neutral lipid composition of high-density and low-density lipoproteins. Atherosclerosis 143: 285-297.

39) Harris WS. 1999. Nonpharmacologic treatment of hypertriglyceridemia: focus on fish oils. Clin Cardiol 22 (6 Suppl): II40-II43.

40) Loeb WF, Quimby FW. 1989. The Clinical Chemistry of Laboratory Animals, Pergamon Press, New York.

41) Mori TA, Vandongen R, Beilin LJ, Burke V, Morris J, Ritchie J. 1994. Effects of varying dietary fat, fish, and fish oils on blood lipids in a randomized controlled trial in men at risk of heart disease. Am J Clin Nutr 59: 1060-1068.

42) Smit MJ, Verkade HJ, Havinga R, Vonk RJ, Scherphof GL, In't Veld G, Kuipers F. 1994. Dietary fish oil potentiates bile acid-induced cholesterol secretion into bile in rats. J Lipid Res 35: 301-310.

43) Tripodi A, Loria P, Dilengite MA, Crulli N. 1991. Effect of fish oil and coconut oil diet on the LDL receptor activity of rat liver plasma membranes. Biochim Biophys Acta 1083: 298-304.
44) Surrette ME, Whelan J, Lu GP, Broughton KS, Kinsella JE. 1992. Dependence on dietary cholesterol for $n-3$ polyunsaturated fatty acid-induced changes in plasma cholesterol in the Syrian Hamster. J Lipid Res 33: 263-271.

45) Hartog JM, Lamers JMJ, Montfoort A, Becker AE, Klompe M, Morse $\mathrm{H}$, ten Cate FJ, van der Werf L, Hulsmann WC, Hugenholtz PG Verdouw PD. 1987. Comparison of mackerel-oil and lard-fat enriched diets on plasma lipids, cardiac membrane phospholipids, cardiovascular performance, and morphology in young pigs. Am J Clin Nutr 46: 258-266.

46) Parks JS, Gebre AK. 1991. Studies on the effect of dietary fish oil on the physical and chemical properties of low density lipoproteins in Cynomolgus Monkeys. J Lipid Res 32: 305-315.

47) Kinsella JE. 1986. Dietary fish oils. Possible effects of n3 polyunsaturated fatty acids in reduction of thrombosis and heart disease. Nutr Today 21: 7-14, 1986.

48) Abramowicz M. 1998. Choice of lipid lowering drugs. Medical Lett 40: 117-122.

49) Kirmani ZA, Baxter CR, Gorman MA, Ashby J, IretonJones C, Liepa GU. 1995. Effects of $\omega-3$ and $\omega-6$ fatty acid-rich oils on the cardiovascular system of thermally injured rabbits: changes in plasma triglycerides, plasma cholesterol, relative blood viscosity, platelet count, and bleeding time. J Burn Care Rehabil 16: 306-316.

50) Nelson GJ, Schmidt PS, Bartolini GL, Kelly DS, Kyle D. 1997. The effect of dietary docosahexaenoic acid on platelet function, platelet fatty acid composition, and blood coagulation in humans. Lipids 32: 1129-1136.

51) Semplicini A, Valle R. 1994. Fish oils and their possible role in the treatment of cardiovascular diseases. Pharmacol Ther 61: 385-397.

52) Kirchgeßner M, Stangl GI, Reichlmayr-Lais AM, Eder K. 1994. The effects of dietary oils on the fatty acid composition and osmotic fragility of erythrocytes. Z Ernährungswiss 33: 146-158.

53) Bartoli GM, Palozza P, Luberto C, Franceschelli P, Piccioni E. 1995. Dietary fish oil inhibits human erythrocyte Mg, NaK-ATPase. Bioch Bioph Res Com 213: 881-887.

54) Mitruka BM, Rawnsley HM, Bharan BV. 1977. Clinical Biochemical and Hematological Reference Values in Normal Experimental Animals, Masson Publishing, New York.

55) Nieuwenhuys CMA, Béguin S, Offermans FG, Emeis JJ, Hornstra G, Heemskerk JWM. 1998. Hypocoagulant and lipid-lowering effects of dietary $n-3$ polyunsaturated fatty acids with unchanged platelet activation in rats. Arterioscler Thromb Vasc Biol 18: 1480-1489.

56) Vognild E, Elvevoll EO, Brox J, Olsen RL, Barstad H, Aursand M, Østerud B. 1998. Effects of dietary marine oils and olive oil on fatty acid composition, platelet membrane fluidity, platelet responses, and serum lipids in healthy humans. Lipids 33: 427-436.

57) Choi YM, Reid T. 1998. Anemia and red cell distribution width at the 12-month well-baby examination. South Med J 91: 372-374.

58) Villegas A, Porres A, Sanchez J, González FA, PerezClausell C, Martínez M, Muga MJ, Cachá J, Lozano M, Fernandez-Fuertes I, Arco AD, Arrizabalaga B, de Mendiguren BP, San Juan I, Saavedra R, Ricart P, Sainz C, Guerra JL, Muñoz JA, Lago C, Ansó VM. 1998. Red blood cell phenotypes in $\alpha$-thalassemias in the Spanish 
population. Hematologica 83: 99-103.

59) Fowler JSL. 1982. Animal clinical chemistry and hematology for the toxicologist. Arch Toxicol Suppl 5: 152-159.

60) Leblanc M, Garred LJ, Cardinal J, Pichette V, Nolin L, Ouimet D, Geadah D. 1998. Catabolism in critical illness: estimation from urea nitrogen appearance and creatinine production during continuous renal replacement therapy. Am J Kidney Dis 32 (3 Suppl): 444-453.

61) Everett RM, Harrison SD Jr. 1983. Clinical biochemistry. In: The Mouse in Biomedical Research (Foster HL, Small JD, Fox JG eds), p 313-326. Academic Press, New York.

62) Wickwire K, Kras K, Gunnett C, Hartle D, Berdanier CD. 1995. Menhaden oil feeding increases potential for renal free radical production in BHE/cdb rats. Proc Soc Exp Biol Med 9: 397-402.

63) Tateno S, Kobayashi Y, Robinson DR. 1997. Dietary fish oil supplementation exacerbate serum sickness nephritis in mice. Nephron 77: 86-89.

64) Bellisola G, Galassini S, Moshini G, Poli G, Perona G, Guidi G. 1992. Selenium and glutathione peroxidase variations induced by polyunsaturated fatty acids oral supplementation in humans. Clin Chem Acta 205: 75-85.

65) Pérez-Granados AM, Vaquero MP, Navarro MP. 1997. Iron metabolism in rats consuming oil from fresh or fried sardines. Analyst 120: 899-903.

66) Farwer SR, Der Boer BCJ, Haddeman E, Kivits GA, Wiersma A, Danse BH. 1994. The vitamin E nutritional status of rats fed on diets high in fish oil, linseed oil or sunflower seed oil. Br J Nutr 72: 127-145.

67) Berlin E, McClure D, Banks MA, Peters RC. 1994. Heart and liver fatty acid composition and vitamin E content in miniature swine fed diets containing corn and menhaden oils. Comp Biochem Physiol 109A: 53-61.

68) Muggli R. 1989. Dietary fish oils increase the requirement for vitamin $\mathrm{E}$ in humans. In: Health Effects of Fish and Fish Oil (Chandra RK, ed), p 201-210. Arts Biomedical Publishers, St. Johns, Newfoundland.

69) Cho SH, Im JG, Choi YS, Son YS, Chung MH. 1995. Lipid peroxidation and 8-hydroxy-deoxyguanosine formation in rats fed fish oil with different levels of vitamin E. J Nutr Sci Vitaminol 41: 61-72. 